\title{
Mampu Bentuk Briket Variasi Bahan Briket dengan Komposisi Perekat serta Waktu Pencelupan Minyak Jelantah
}

\author{
Able to Form Briquette from Briquette Material \\ Variation with Adhesive Composition and Waste Oil \\ Immersion Timing
}

\author{
Mohammad Nurhilal \\ Program Studi Teknik Mesin, Politeknik Negeri Cilacap, Jl Dr. Soetomo No.1 \\ Sidakaya Cilacap 53212 Telp. (0282) 533329 Faksmile (0282) 537992 \\ najiwaa@yahoo.com
}

\begin{abstract}
Indonesia is given with abundant natural wealth which is capable of being transformed into source of energy. However, the utilization of these natural resources can not yet be optimized. An alternative solution to make fuel is briquette fuel. The general purpose of this research is to make briquettes of rice husk and garlic skin. While the specific purpose of this research is to know the result of briquette variation of adhesive material and briquette material with adhesive as well as time of reused oil dipping. The method of this research is experiment approach. The results showed that starch glue can be used as briquettes of rice husk and garlic skin; mixed variations of $60 \%, 70 \%$ and $80 \%$ starch glue blends were able to form briquettes; variations of pulp mixture $20 \%, 30 \%$ and $40 \%$ and without mixing the pulp can form briquettes; and the variation of briquette dyeing time of 1,3 , and 5 minutes had no effect on briquette solidity.
\end{abstract}

Keywords: Briquette, rice husk charcoal, garlic skin charcoal, adhesive, solidity.

\section{PENDAHULUAN}

Masalah krisis energi di masa yang akan datang memang tidak dapat dianggap sebagai permasalahan pemerintah maupun instansi terkait saja, akan tetapi sudah menjadi perhatian bagi masyarakat khususnya dari kalangan pemerhati maupun akademisi sebagai pengembang Ilmu dan Teknologi. Salah satu tantangan yang harus di temukan solusinya adalah dengan menciptakan maupun menginovasi tentang pengembangan sumber energi baru.

Briket bagi lingkungan masyarakat sudah dikenal cukup lama, akan tetapi penggunaan briket oleh masyarakat untuk kebutuhan rumah tangga kurang banyak mendapat apresiasi. Kondisi ini dimungkinkan ketika terjadi kenaikan minyak tanah, pada saat itu juga pemerintah memberikan bantuan pemberian tabung gas secara cuma-cuma, dengan tujuan subsidi yang dialokasikan untukminyak akan dialihkan untuk penggunaan pada bahan bakar gas. Masalah ini berdampak besar pada industri dan pengusaha briket yang tidak mampu menjual produksinya. Di sisi lain, bahan baku briket masih menggunakan batubara menjadikan harga briket masih tinggi, hal itu yang menjadi faktor kurangnya ke tertarikan masyarakat untuk beralih ke briket. Untuk mengatasi masalah tersebut adalah optimalisasi sumber daya alam baik bahan-bahan limbah yang dapat dibuat menjadi briket. Dengan adanya bahan bakar alternatif yang murah, maka dimungkinkan akan mengembalikan ketertarikan masyarakat untuk beralih menggunakan briket. Sehingga, keadaan ini juga akan membangkitkan produktivitas pada industri pembuat briket. Pentingnya penanganan masalah bahan bakar alternatif menjadi permasalahan yang terus dikaji di berbagai penelitian. Tujuan dalam penelitian ini akan mengkaji kemampuan bentuk briket arang sekam padi dan kulit bawang putih dengan berbagai variasi pencampuran komposisi perekat serta waktu ketika dicelupkan dalam minyak jelantah.

Kajian tentang pembuatan briket diantaranya oleh Aquino, (2010) meneliti "Pengaruh Variasi Jumlah Campuran Perekat Terhadap Karakteristik Briket Arang Tongkol Jagung”. Hapsoro, D. S, (2010) dalam penelitian tentang Pengaruh Kandungan Lem Kanji Terhadap Sifat Tarik dan Densitas Komposit Koran Bekas. Dan Maryani (2010) meneliti tentang Pengaruh Faktor Jenis Kertas, Jenis Perekat Dan Kerapatan Komposit Terhadap Kekuatan Impak Pada Komposit Panel Serap Bising Berbahan Dasar Limbah Kertas. 
Mohammad Nurhilal. Mampu Bentuk Briket Variasi Bahan Briket dengan Komposisi Perekat serta Waktu Pencelupan Minyak Jelantah.

Limbah bawang putih merupakan bagian luar bawang terdiri dari kulit berwarna putih, tangkai dan tongkol. Limbah bawang banyak dihasilkan dari proses-proses pengolahan makanan sebagai bahan bumbu pada industri makanan. Keberadaan limbah sekarang telah ditampung yang selanjutnya akan di jual kembali pada masyarakat yang membutuhkan.

Sekam padi merupakan lapisan keras yang meliputi kariopsis yang terdiri dari dua belahan yang disebut lemma dan palea yang saling bertautan. Pada proses penggilingan beras sekam akan terpisah dari butir berasdan menjadi bahan sisa atau limbah penggilingan. Sekam dikategorikan sebagai biomassa yang dapat digunakan untuk berbagai kebutuhan seperti bahan aku industri, pakan ternak dan energi atau bahan bakar.

Paste merupakan perekat pati (starch) yang dibuat melalui pemanasan campuran pati dan air dan diperthankan berbentuk pasta. Cement adalah istilah yang digunakan untuk perekat yang bahan dasarnya karet dan mengeras melalui pelepasan pelarut (Vick.C.B. 1999).

Kertas terutama terdiri dari serat selulosa yang diperoleh dari kayu atau bahan selulosa lainnya yang melalui salah satu proses pembuatan pulp. Sifat kekuatan dan mekanisnya bergantung pada perlakuan mekanis pada serat serta pada penambahan bahan pengisi dan pengikat. Struktur dasar bubur kertas (pulp) dan kertas adalah feltedmat dari serat selulosa (www.arsipjatim.go.id).

\section{METODOLOGI}

Tahapan-tahapan penelitian ini meliputi:

a. Pengarangan bahan briket

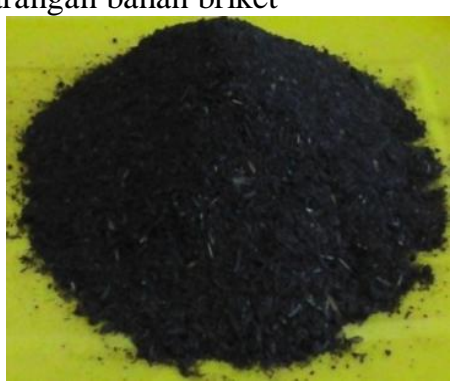

(a)

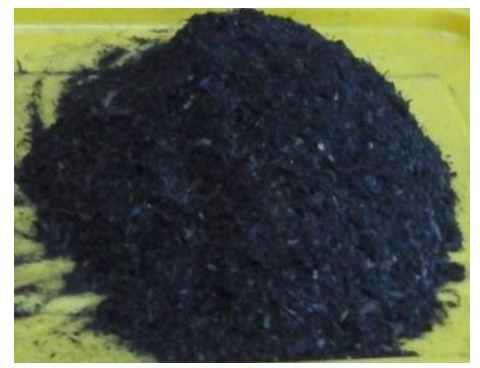

(b)

Gambar 1. (a) Arang sekam padi; (b) Arang kulit bawang putih

b. Pembuatan perekat

Perekat briket menggunakan bubur kertas dan tepung kanji.

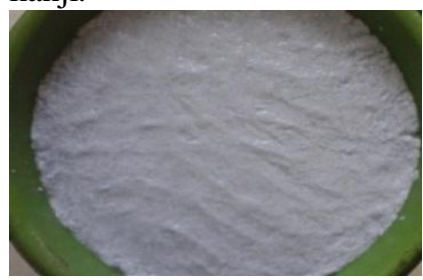

(a)

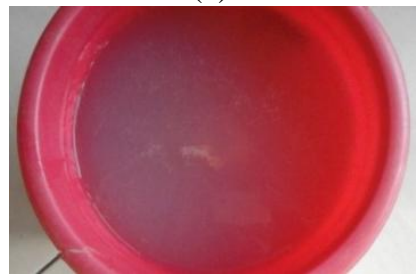

(b)

Gambar 3. (a) Bubur kertas; (b) lem kanji.

c. Pencetakan briket

Proses pencetakan briket melalui tahapantahapan berikut ini: a) pencampuran arang briket dengan perekat sesuai dengan variasi komposisi tepung kanji 40, 50, dan 60 gram di ambil masing-masing 60, 70, dan $80 \mathrm{w} / \mathrm{w}$ dan dicampur dengan bubur kertas masing-masing 20, 30, dan 40 w/w dengan tiap-tiap bahan briket; b) pencetakan briket; dan c) pengeringan.

d. Pengujian briket

Pengujian briket dalam penelitian ini adalah : a) pengujian hasil cetak adonan dari masing-masing campuran bahan briket dan perekat; b) pengamatan hasil briket dari masing-masing campuran bahan briket dan perekat; dan c) ketahanan briket terhadap variasi waktu pencelupan minyak jelantah.

\section{HASIL DAN PEMBAHASAN}

3.1 Hasil Cetak Adonan dari Masing-Masing Campuran Bahan Briket dan Perekat.

Bahan baku yang digunakan dalam penelitian ini terdiri dari arang sekam padi dan arang kulit bawang putih serta dengan perekat lem tepung kanji dan bubur kertas. Analisis bertujuan untuk mengetahui apakah setiap perbandingan komposisi campuran bahan baku bisa dicetak atau tidak. Data hasil analisa dapat dilihat pada tabel 4.1. 
TABEL 4.1 PERBANDINGAN KOMPOSISI CAMPURAN TIAP SAMPLE

\begin{tabular}{|c|c|c|c|c|c|c|c|}
\hline \multirow[b]{3}{*}{ Sample } & \multicolumn{4}{|c|}{ Perekat } & \multirow{3}{*}{$\begin{array}{c}\text { Arang } \\
\text { Sekam Padi } \\
\text { (gram) }\end{array}$} & \multirow{3}{*}{$\begin{array}{c}\text { Arang Kulit } \\
\text { Bawang Putih } \\
\text { (gram) }\end{array}$} & \multirow{3}{*}{ Hasil Cetak } \\
\hline & \multicolumn{3}{|c|}{ Lem Tepung kanji (gram) } & \multirow{2}{*}{$\begin{array}{c}\text { Bubur } \\
\text { Kertas (\%) }\end{array}$} & & & \\
\hline & 40 & 50 & 60 & & & & \\
\hline 1 & 60 & & & 40 & 100 & 100 & Bisa \\
\hline 2 & & 60 & & 40 & 100 & 100 & Bisa \\
\hline 3 & & & 60 & 40 & 100 & 100 & Bisa \\
\hline 4 & 70 & & & 30 & 100 & 100 & Bisa \\
\hline 5 & & 70 & & 30 & 100 & 100 & Bisa \\
\hline 6 & & & 70 & 30 & 100 & 100 & Bisa \\
\hline 7 & 80 & & & 20 & 100 & 100 & Bisa \\
\hline 8 & & 80 & & 20 & 100 & 100 & Bisa \\
\hline 9 & & & 80 & 20 & 100 & 100 & Bisa \\
\hline 10 & 60 & & & 40 & 100 & 100 & Bisa \\
\hline 11 & & 70 & & 30 & 100 & 100 & Bisa \\
\hline 12 & & & 80 & 20 & 100 & 100 & Bisa \\
\hline 13 & 100 & & & Tanpa & 100 & 100 & Bisa \\
\hline 14 & & 100 & & Tanpa & 100 & 100 & Bisa \\
\hline 15 & & & 100 & Tanpa & 100 & 100 & Bisa \\
\hline
\end{tabular}

3.2 Analisa Hasil Briket dari Masing-Masing Campuran Bahan Briket dan Perekat.

Analisa selanjutnya adalah pengamatan hasil briket dari masing-masing bahan briket dan campuran komposisi perekat. Hal ini bertujuan untuk mengetahui apakah setiap perbandingan komposisi campuran bahan baku menghasilkan briket yang sempurna atau tidak.

TABel 4.2 Hasil Briket Arang SeKam Padi Komposisi CAMPURAn Tiap SAMPLE

\begin{tabular}{|c|c|c|c|c|c|c|c|}
\hline \multirow{3}{*}{ Sample } & \multicolumn{4}{|c|}{ Perekat } & \multirow{3}{*}{$\begin{array}{l}\text { Arang } \\
\text { Sekam } \\
\text { Padi } \\
\text { (gram) }\end{array}$} & \multirow{3}{*}{$\begin{array}{c}\text { Hasil } \\
\text { Briket }\end{array}$} & \multirow{3}{*}{ Keterangan } \\
\hline & \multicolumn{3}{|c|}{$\begin{array}{l}\text { Lem Tepung kanji } \\
\text { (gram) }\end{array}$} & \multirow{2}{*}{$\begin{array}{c}\text { Bubur } \\
\text { Kertas } \\
(\%)\end{array}$} & & & \\
\hline & 40 & 50 & 60 & & & & \\
\hline & & & & & & & $\begin{array}{l}\text { Permukaan rata, tidak terdapat retak pada } \\
\text { bagian sisi, bagian atas miring } \\
\text { dikarenakan kondisi penenkan miring }\end{array}$ \\
\hline 2 & & $60 \%$ & & 40 & 100 & & $\begin{array}{l}\text { Permukaan rata, tidak terdapat retak pada } \\
\text { bagian sisi, bagian atas miring } \\
\text { dikarenakan kondisi penenkan miring }\end{array}$ \\
\hline 3 & & & $60 \%$ & 40 & 100 & & $\begin{array}{l}\text { Permukaan rata, terdapat retak menjalar } \\
\text { pada bagian sisi atas }\end{array}$ \\
\hline 4 & $70 \%$ & & & 30 & 100 & & $\begin{array}{l}\text { Permukaan rata, terdapat retak menjalar } \\
\text { pada bagian sisi atas }\end{array}$ \\
\hline 5 & & $70 \%$ & & 30 & 100 & & $\begin{array}{l}\text { Permukaan rata, terdapat retak menjalar } \\
\text { pada bagian sisi atas }\end{array}$ \\
\hline 6 & & & $70 \%$ & 30 & 100 & & $\begin{array}{l}\text { Permukaan rata, terdapat retak menjalar } \\
\text { pada bagian sisi atas }\end{array}$ \\
\hline
\end{tabular}


Mohammad Nurhilal. Mampu Bentuk Briket Variasi Bahan Briket dengan Komposisi Perekat serta Waktu Pencelupan Minyak Jelantah.

\begin{tabular}{|c|c|c|c|c|c|c|}
\hline 7 & $80 \%$ & & & 20 & 100 & $\begin{array}{l}\text { Permukaan rata, terdapat retak menjalar } \\
\text { pada bagian sisi atas, bagian atas miring } \\
\text { dikarenakan kondisi penenkan miring }\end{array}$ \\
\hline 8 & & $80 \%$ & & 20 & 100 & $\begin{array}{l}\text { Permukaan rata, tidak terdapat retak } \\
\text { menjalar pada bagian sisi }\end{array}$ \\
\hline 9 & & & $80 \%$ & 20 & 100 & $\begin{array}{l}\text { Permukaan rata, tidak terdapat retak } \\
\text { menjalar pada bagian sisi }\end{array}$ \\
\hline 10 & $60 \%$ & & & 40 & 100 & $\begin{array}{l}\text { Permukaan rata, tidak terdapat retak } \\
\text { menjalar pada bagian sisi }\end{array}$ \\
\hline 11 & $70 \%$ & & & 30 & 100 & $\begin{array}{l}\text { Permukaan rata, tidak terdapat retak } \\
\text { menjalar pada bagian sisi atas }\end{array}$ \\
\hline 12 & $80 \%$ & & & 20 & 100 & $\begin{array}{l}\text { Permukaan rata, tidak terdapat retak } \\
\text { menjalar pada bagian sisi atas, bagian } \\
\text { atas miring dikarenakan penenkan miring }\end{array}$ \\
\hline 13 & $100 \%$ & & & Tanpa & 100 & $\begin{array}{l}\text { Permukaan rata, terdapat retak menjalar } \\
\text { pada bagian sisi bawah }\end{array}$ \\
\hline 14 & & $100 \%$ & & Tanpa & 100 & $\begin{array}{l}\text { Permukaan rata, terdapat retak menjalar } \\
\text { pada bagian sisi bawah, bagian atas } \\
\text { miring dikarenakan penenkan miring }\end{array}$ \\
\hline 15 & & & $100 \%$ & Tanpa & 100 & $\begin{array}{l}\text { Permukaan rata, terdapat retak menjalar } \\
\text { pada bagian sisi atas, bagian atas miring } \\
\text { dikarenakan kondisi penenkan miring }\end{array}$ \\
\hline
\end{tabular}

Tabel 4.3 Hasil Briket Arang Kulit Bawang Putih Komposisi CAmpuran Tiap Sample

\begin{tabular}{|c|c|c|c|c|c|c|c|}
\hline \multirow{3}{*}{ Sample } & \multicolumn{4}{|c|}{ Perekat } & \multirow{3}{*}{$\begin{array}{c}\text { Arang } \\
\text { Sekam } \\
\text { Padi } \\
\text { (gram) }\end{array}$} & \multirow{3}{*}{$\begin{array}{c}\text { Hasil } \\
\text { Briket }\end{array}$} & \multirow{3}{*}{ Keterangan } \\
\hline & \multicolumn{3}{|c|}{$\begin{array}{l}\text { Lem Tepung kanji } \\
\text { (gram) }\end{array}$} & \multirow{2}{*}{$\begin{array}{c}\text { Bubur } \\
\text { Kertas } \\
(\%)\end{array}$} & & & \\
\hline & 40 & 50 & 60 & & & & \\
\hline 1 & $60 \%$ & & & 40 & 100 & & $\begin{array}{l}\text { Permukaan rata, terdapat retak menjalar } \\
\text { merata terutama pada bagian sisi tengah }\end{array}$ \\
\hline 2 & & $60 \%$ & & 40 & 100 & & $\begin{array}{l}\text { Permukaan rata, tidak terdapat retak pada } \\
\text { bagian sisi }\end{array}$ \\
\hline 3 & & & $60 \%$ & 40 & 100 & & $\begin{array}{l}\text { Permukaan rata, tidak terdapat retak pada } \\
\text { bagian sisi }\end{array}$ \\
\hline
\end{tabular}


Jurnal Ilmiah INOVASI, Vol. 18 No. 1 Edisi Januari April 2018, ISSN 1411-5549

\begin{tabular}{|c|c|c|c|c|c|c|}
\hline 4 & $70 \%$ & & & 30 & 100 & $\begin{array}{l}\text { Permukaan rata, tidak terdapat retak pada } \\
\text { bagian sisi }\end{array}$ \\
\hline 5 & & $70 \%$ & & 30 & 100 & $\begin{array}{l}\text { Permukaan rata, tidak terdapat retak pada } \\
\text { bagian sisi }\end{array}$ \\
\hline 6 & & & $70 \%$ & 30 & 100 & $\begin{array}{l}\text { Permukaan rata, tidak terdapat retak pada } \\
\text { bagian sisi }\end{array}$ \\
\hline 7 & $80 \%$ & & & 20 & 100 & $\begin{array}{l}\text { Permukaan rata, tidak terdapat retak pada } \\
\text { bagian sisi }\end{array}$ \\
\hline 8 & & $80 \%$ & & 20 & 100 & $\begin{array}{l}\text { Permukaan rata, tidak terdapat retak pada } \\
\text { bagian sisi, sisi atas, bagian atas miring } \\
\text { dikarenakan kondisi penenkan miring }\end{array}$ \\
\hline 9 & & & $80 \%$ & 20 & 100 & $\begin{array}{l}\text { Permukaan rata, tidak terdapat retak pada } \\
\text { bagian sisi }\end{array}$ \\
\hline 10 & $60 \%$ & & & 40 & 100 & $\begin{array}{l}\text { Permukaan rata, terdapat retak menjalar } \\
\text { terutama pada bagian sisi atas }\end{array}$ \\
\hline 11 & & $70 \%$ & & 30 & 100 & $\begin{array}{l}\text { Permukaan rata, tidak terdapat retak pada } \\
\text { bagian sisi }\end{array}$ \\
\hline 12 & & & $80 \%$ & 20 & 100 & $\begin{array}{l}\text { Permukaan rata, tidak terdapat retak pada } \\
\text { bagian sisi }\end{array}$ \\
\hline 13 & $100 \%$ & & & Tanpa & 100 & $\begin{array}{l}\text { Permukaan rata, terdapat retak menjalar } \\
\text { terutama pada bagian sisi atas }\end{array}$ \\
\hline 14 & & $100 \%$ & & Tanpa & 100 & $\begin{array}{l}\text { Permukaan rata, terdapat retak menjalar pada } \\
\text { bagian sisi atas, bagian atas miring } \\
\text { dikarenakan kondisi penenkan miring }\end{array}$ \\
\hline 15 & & & $100 \%$ & Tanpa & 100 & $\begin{array}{l}\text { Permukaan rata, terdapat retak menjalar } \\
\text { terutama pada bagian sisi atas }\end{array}$ \\
\hline
\end{tabular}


Mohammad Nurhilal. Mampu Bentuk Briket Variasi Bahan Briket dengan Komposisi Perekat serta Waktu Pencelupan Minyak Jelantah.

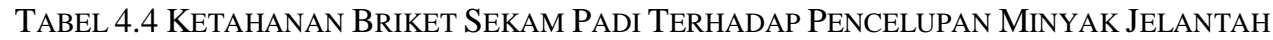

\begin{tabular}{|c|c|c|c|c|c|c|c|c|c|}
\hline \multirow{3}{*}{ Sample } & \multicolumn{4}{|c|}{ Perekat } & \multirow{2}{*}{\multicolumn{3}{|c|}{$\begin{array}{c}\text { Waktu } \\
\text { Pencelupan } \\
\text { (menit) }\end{array}$}} & \multirow{3}{*}{$\begin{array}{c}\text { Hasil } \\
\text { Briket }\end{array}$} & \multirow{3}{*}{ Keterangan } \\
\hline & \multicolumn{3}{|c|}{$\begin{array}{l}\text { Lem Tepung kanji } \\
\text { (gram) }\end{array}$} & \multirow{2}{*}{$\begin{array}{c}\text { Bubur } \\
\text { Kertas } \\
(\%)\end{array}$} & & & & & \\
\hline & 40 & 50 & 60 & & 1 & 3 & 5 & & \\
\hline 1 & $60 \%$ & & & 40 & $\sqrt{ }$ & & & & $\begin{array}{l}\text { Hasil briket masih solid sama dengan } \\
\text { sebelum dicelupkan minyak jelantah }\end{array}$ \\
\hline 2 & & $60 \%$ & & 40 & $\sqrt{ }$ & & & & $\begin{array}{l}\text { Hasil briket masih solid sama dengan } \\
\text { sebelum dicelupkan minyak jelantah }\end{array}$ \\
\hline 3 & & & $60 \%$ & 40 & $\sqrt{ }$ & & & & $\begin{array}{l}\text { Hasil briket masih solid sama dengan } \\
\text { sebelum dicelupkan minyak jelantah }\end{array}$ \\
\hline 4 & $70 \%$ & & & 30 & & $\sqrt{ }$ & & & $\begin{array}{l}\text { Hasil briket masih solid sama dengan } \\
\text { sebelum dicelupkan minyak jelantah }\end{array}$ \\
\hline 5 & & $70 \%$ & & 30 & & $\sqrt{ }$ & & & $\begin{array}{l}\text { Hasil briket masih solid sama dengan } \\
\text { sebelum dicelupkan minyak jelantah }\end{array}$ \\
\hline 6 & & & $70 \%$ & 30 & & $\sqrt{ }$ & & & $\begin{array}{l}\text { Hasil briket masih solid sama dengan } \\
\text { sebelum dicelupkan minyak jelantah }\end{array}$ \\
\hline 7 & $80 \%$ & & & 20 & & & $\sqrt{ }$ & & $\begin{array}{l}\text { Hasil briket masih solid sama dengan } \\
\text { sebelum dicelupkan minyak jelantah }\end{array}$ \\
\hline 8 & & $80 \%$ & & 20 & & & $\sqrt{ }$ & & $\begin{array}{l}\text { Hasil briket masih solid sama dengan } \\
\text { sebelum dicelupkan minyak jelantah }\end{array}$ \\
\hline 9 & & & $80 \%$ & 20 & & & $\sqrt{ }$ & & $\begin{array}{l}\text { Hasil briket masih solid sama dengan } \\
\text { sebelum dicelupkan minyak jelantah }\end{array}$ \\
\hline
\end{tabular}

Tabel 4.5 Ketahanan Briket Kulit Bawang Putih Terhadap Pencelupan Minyak Jelantah

\begin{tabular}{|c|c|c|c|c|c|c|c|c|c|}
\hline \multirow[t]{3}{*}{ Sample } & \multicolumn{4}{|c|}{ Perekat } & \multirow{2}{*}{\multicolumn{3}{|c|}{$\begin{array}{c}\text { Waktu } \\
\text { pencelupan } \\
\text { (menit) }\end{array}$}} & \multirow{3}{*}{$\begin{array}{c}\text { Hasil } \\
\text { Briket }\end{array}$} & \multirow{3}{*}{ Keterangan } \\
\hline & \multicolumn{3}{|c|}{$\begin{array}{l}\text { Lem Tepung kanji } \\
\text { (gram) }\end{array}$} & \multirow{2}{*}{$\begin{array}{c}\text { Bubur } \\
\text { kertas } \\
(\%)\end{array}$} & & & & & \\
\hline & 40 & 50 & 60 & & 1 & 3 & 5 & & \\
\hline 1 & $60 \%$ & & & 40 & $\sqrt{ }$ & & & & $\begin{array}{l}\text { Hasil briket masih solid sama dengan } \\
\text { sebelum dicelupkan minyak jelantah }\end{array}$ \\
\hline 2 & & $60 \%$ & & 40 & & $\sqrt{ }$ & & & $\begin{array}{l}\text { Hasil briket masih solid sama dengan } \\
\text { sebelum dicelupkan minyak jelantah }\end{array}$ \\
\hline
\end{tabular}




\begin{tabular}{|c|c|c|c|c|c|c|c|c|}
\hline 3 & & & $60 \%$ & 40 & & & $\sqrt{ }$ & $\begin{array}{l}\text { Hasil briket masih solid sama dengan } \\
\text { sebelum dicelupkan minyak jelantah }\end{array}$ \\
\hline 4 & $70 \%$ & & & 30 & $\sqrt{ }$ & & & $\begin{array}{l}\text { Hasil briket masih solid sama dengan } \\
\text { sebelum dicelupkan minyak jelantah }\end{array}$ \\
\hline 5 & & $70 \%$ & & 0 & & $\sqrt{ }$ & & $\begin{array}{l}\text { Hasil briket masih solid sama dengan } \\
\text { sebelum dicelupkan minyak jelantah }\end{array}$ \\
\hline 6 & & & $70 \%$ & 30 & & & $\sqrt{ }$ & $\begin{array}{l}\text { Hasil briket masih solid sama dengan } \\
\text { sebelum dicelupkan minyak jelantah }\end{array}$ \\
\hline 7 & $80 \%$ & & & 20 & $\sqrt{ }$ & & & $\begin{array}{l}\text { Hasil briket masih solid sama dengan } \\
\text { sebelum dicelupkan minyak jelantah }\end{array}$ \\
\hline 8 & & $80 \%$ & & 20 & & $\sqrt{ }$ & & $\begin{array}{l}\text { Hasil briket masih solid sama dengan } \\
\text { sebelum dicelupkan minyak jelantah }\end{array}$ \\
\hline 9 & & & $80 \%$ & 20 & & & $\sqrt{ }$ & $\begin{array}{l}\text { Hasil briket masih solid sama dengan } \\
\text { sebelum dicelupkan minyak jelantah }\end{array}$ \\
\hline
\end{tabular}

\subsection{Pembahasan}

Hasil cetak briket arang sekam padi dan arang kulit bawang putih dari masing-masing komposisi campuran perekat dapat dibentuk/dicetak. Tabel 4.1 menjelaskan bahwa bahan briket arang sekam padi dan arang kulit bawang putih dapat dicetak dengan variasi campuran komposisi perekat.

Tabel 4.2 dijelaskan hasil briket arang sekam padi variasi komposisi perekat. Secara keseluruhan variasi perekat 60,70 , dan $80 \%$ dengan penambahan bubur kertas 20, 30, dan $40 \%$ pada briket arang sekam padi dan briket arang kulit bawang putih menghasilkan permukaan yang rata, meskipun ada beberapa briket pada bagian sisi permukaan terdapat retak-retak yang tidak sama posisinya. Retak-retak briket tersebut dikarenakan faktor pengepresan/pencetakan briket, dimana kondisi bagian dalam cetakan kering/tidak ada pelicin sehingga gaya penekanan yang dihasilkan untuk proses penekanan menjadi besar. Kondisi ini juga yang mengakibatkan briket akan sulit keluar dalam cetakan, dikarenakan faktor kondisi dinding cetakan yang kering.

Faktor dasar dari sulitnya briket keluar dari cetakan sebenarnya lebih pada faktor gesekan, dimana pada saat proses penekanan terdapat gaya gesekan yang besar antara permukaan sisi briket dengan dinding cetakan. Faktor gesekan merupakan gejala yang normal, dimana jika terdapat pergerakan suatu benda terhadap bidang dasar maka akan terdapat gaya gesekan.

Hasil cetak briket pada masing-masing variasi perekat dan masing-masing bahan briket pada permukaan bagian atas miring, kondisi ini dikarenakan lebih pada faktor teknis alat, dan proses pengeprepasan, faktor alat dikarenakan penempatan penekan yang miring, sehingga penekanan pada cetakan mengikuti posisi dari penekan. Sedangkan faktor proses dikarenakan kondisi pada kurang ketelitian penempatan penekan yang tidak persisi dengan bahan ketika akan di tekan, sehingga faktorfaktor tersebut yang yang mengakibatkan briket pada sisi permukaan bagian atas miring.

Faktor lain yang mempengaruhi mampu cetak briket juga dipengaruhi oleh faktor perekat. Umumnya, komposisi tepung kanji yang lebih banyak akan menghasilkan daya rekat tinggi, dimana daya rekat lem yang tinggi ketika dicampurkan dengan bahan briket maka akan menghasilkan soliditas briket juga tinggi, dikarenakan ikatan partikel bahan briket juga akan tinggi. Faktor campuran komposisi perekat juga berhubungan dengan mampu bentur briket, dimana semakin banyak perekat yang digunakan dalam campuran bahan briket maka daya benturan briket juga akan meningkat. Hal ini sesuai dengan 
Mohammad Nurhilal. Mampu Bentuk Briket Variasi Bahan Briket dengan Komposisi Perekat serta Waktu Pencelupan Minyak Jelantah.

hasil penelitian Aquino, (2010) yang menjelaskan faktor pengaruh campuran perekat terhadap sifat fisik briket, dimana semakin banyak campuran perekat, daya tahan briket terhadap benturan semakin besar sehingga banyak partikel yang hilang. Jadi, soliditas briket juga sangat berkaitan erat dengan mampu bentur briket ketika mendapatkan beban/gaya luar.

Tujuan yang lebih penting pencelupan briket ke dalam minyak tanah sebenarnya adalah karena faktor untuk meningkatkan kalori briket, dimana studi referensi yang menyatakan bahwa minyak jelantah dapat dijadikan bahan bakar melalui proses-prose kimia untuk menghasilkan nilai kalor dalam minyak jelantah. Sehingga dengan pengujian waktu pencelupan briket ke dalam minyak jelantah dengan variasi waktu yang berbeda dapat diketahui pengaruhnya terhadap nilai kalor briket tersebut.

Hasil pengujian variasi waktu pencelupan briket ke dalam minyak jelantah dari masing-masing variasi komposisi perekat dan bahan briket secara keseluruhan tidak berpengaruh terhadap kondisi soliditas/keutuhan briket, meskipun dengan variasi yang berbeda-beda yaitu 1, 3, dan 5 menit pencelupan minyak jelantah. Secara umum, waktu pencelupan yang lama akan berpengaruh terhadap soliditas/keutuhan briket, dimana waktu pencelupan 5 menit dapat mempengaruhi cairan minyak jelantah lebih rata masuk kedalam permkaan briket, sehingga kondisi ini dapat berakibat pada penguraian partikel bahan briket. Masalah ini hanya berakibat pada campuran komposisi perekat yang rendah, sehingga daya rekat terhadap bahan briket juga rendah, dikarenakan ikatan partikel juga rendah. Hasil ini juga dapat menggambarkan bahwa lem tepung kanji dan penambahan bubur kertas sebagai bahan campuran perekat mampu digunakan untuk perekat.

Hasil penelitian ini juga dilandasi dengan penelitian Aquino, (2010) meneliti Pengaruh Variasi Jumlah Campuran Perekat Terhadap Karakteristik Briket Arang Tongkol Jagung, dan penelitian oleh Hapsoro, D. S, (2010) dalam penelitian tentang Pengaruh Kandungan Lem Kanji Terhadap Sifat Tarik dan Densitas Komposit Koran Bekas. Dimana dari kedua penilitian tersebut menjelaskan bahwa penggunaan lem tepung kanji untuk bahan perekat briket dan juga untuk bahan perekat komposit.

\section{KESIMPULAN DAN SARAN}

\subsection{Kesimpulan}

a. Lem kanji dapat digunakan sebagai perekat briket arang sekam padi dan briket arang kulit bawang putih.

b. Variasi campuran lem tepung kanji $60 \%, 70 \%$ dan $80 \%$ mampu dibentuk briket.

c. Campuran bubur kertas 20\%, 30\% dan $40 \%$ dan tanpa pencampuran bubur kertas mampu dibentuk briket. d. Waktu pencelupan briket 1, 3, dan 5 menit tidak berpengaruh terhadap soliditas briket.

\subsection{Saran}

Saran hasil penelitian ini antara lain

a. Penelitian ini masih perlu dikembangkan ke arah analisa karakteristik hasil briket, sehingga dapat diketahui mutu hasil uji karakteristik briket.

b. Hasil penelitian ini dapat dikembangkan pada pemanfaatn bahan-bahan lain untuk pembuatan briket, sehingga dapat diketahui nilai kemafaatannya

\section{UCAPAN TERIMAKASIH}

Ucapan terimakasih disampaikan kepada PPPM Politeknik Negeri Cilacap yang telah menjembati dalam pembiayaan penelitian di tahun 2016.

\section{DAFTAR PUSTAKA}

[1] Aquino, G. B. 2010. Pengaruh Variasi Jumlah Campuran Perekat Terhadap Karakteristik Briket Arang Tongkol Jagung. Jurnal Provesional, Vol. 8, No. 1 .

[2] Hapsoro, D. S. 2010.Pengaruh Kandungan Lem Kanji Terhadap Sifat Tarik dan Densitas Komposit Koran Bekas. Tugas Akhir. Jurusan Teknik Mesin Universitas Sebelas Maret. Surakarta.

[3] http://fajrianifpt.blogspot.com/2010/05/tugaskuliah.html

[4] Maryani. 2010. Pengaruh Faktor Jenis Kertas, Jenis Perekat dan Kerapatan Komposit Terhadap Kekuatan Impak Pada Komposit Panel Serap Bising Berbahan Dasar Limbah Kertas. Skripsi S1, Teknik Industri, Universitas Sebelas Maret. Surakarta.

[5] Vick.C.B. 1999. "Adhesive Bonding of Wood Material”. Chapter: IX. Wood Handbook, Wood as an Engineering Material. Forest Product Society. USA. 